\title{
LIDANDO COM A RELIGIÃO NO AMBIENTE ORGANIZACIONAL
}

\section{Por Glaucia Tristão Pupim Bisi}

Mestre em Administração de Empresas pela UFES

E-mail: glauciatristao@gmail.com

\section{Por Marilene Olivier}

Professora da Universidade Federal do Espírito Santo. Doutora em Administração de Empresas pela USP

E-mail: molivier@terra.com.br

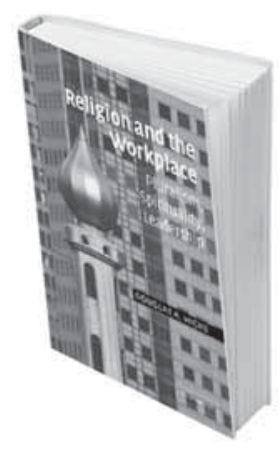

\section{RELIGION AND THE WORKPLACE}

De Douglas A. Hicks

Cambridge University Press, Cambridge, 2003, 222 p.

Religion and the Workplace é um livro dedicado à compreensão da presença da religião no ambiente de trabal ho, seja por pesquisadores do tema ou por aqueles que deparam com a questão em seu cotidiano. Contraria as publicações norte-americanas, na sua maioria funcionalistas, que abordam o relacionamento entre liderança e religião nas organizações por meio de model os que visam primordialmente a lucratividade.
N o esforço de entender as relações da religião no ambiente de trabalho, 0 autor utiliza pesquisadores de vários campos do conhecimento e busca oferecer idéias que podem capacitar a expansão de entendimentos sobre 0 ambiente de trabal ho como um importante contexto público no qual a religião, em toda a sua diversidade, opera. Além disso, convida filósofos, teólogos e especialistas em ética de tradições específicas a desenvolver perspectivas sobre trabal ho, ética nos negócios e liderança organizacional que se voltem ao desafio da diversidade da força de trabalho. Encoraja pesquisadores da administração e dos estudos em liderança a entender a religião, em suas múltiplas e potenciais formas de conflito, como uma importante parte da identidade de muitos empregados que deve ser respeitada em vez de evitada, reduzida e explorada. 
A proposta central da obra está relacionada com a defesa do modelo de respeito ao pluralismo, que, segundo o autor, apesar de não resolver todos os dilemas envolvidos com a religiosidade no ambiente de trabal ho, fomenta uma conversação crítica entre os pesquisadores e os que vivenciam na prática a questão da atuação religiosa no ambiente organizacional.

0 model o pluralista sugerido cria espaços onde empregados de vários níveis hierárquicos da organização podem ser agentes morais e expressar perspectivas diferentes no trabal ho. Isso porque a espiritualidade ou religiosidade de um ambiente de trabalho não obedece necessariamente à hierarquia da organização. Os líderes, formais ou não, têm um papel crucial em dar forma e manter uma estrutura e cultura de respeito ao pluralismo, mas todos os empregados podem ativamente se engajar em tal condição. Dessa forma, as lideranças não seriam as únicas responsáveis pela criação de um processo e procedimento no qual os empregados possam comunicar seus comprometimentos e crenças.

o livro traz várias definições de religião e suas controvérsias, enfatizando a necessidade de maior precisão dos pesqui sadores no uso dessas expressões, na tentativa de captar mais adequadamente as distintas realidades das formas múltiplas de religião. Além disso, pelos casos estudados, o mundo organizacional apresenta grandes variações referentes ao tema, o que requer análises mais acuradas sobre as relações entre ambiente de trabalho e religião, considerando-se o tamanho, a estrutura, a cultura e a história de cada organização.

Sobre a discussão das formas como os empregados expressam suas diferentes religiões no traba-
Iho, enfatiza-se que funcionários de empresas com lideranças que valorizem sua participação tenderão a ver a espiritualidade de forma diferente de empregados de organizações com uma história de desconfiança e tensão no ambiente de trabalho. Assim, percebe-se que o discurso e as ações rel acionadas com a influência da religião no ambiente de trabalho podem operar em duas vias, dependendo não só da natureza da religião, mas também da natureza da organização.

Além disso, estudos comparativos entre diferentes nações mostram que o contexto político e legal também atua de forma decisiva no entendimento da religiosidade no ambiente de trabalho. Isso pode ser visto pelas diferentes questões abordadas por pesquisadores em seus países, tais como leis de direitos civis e feriados nacionais religiosos.

Também faz parte da análise do livro a questão da importância de se entender o conjunto de idéias religiosas na vida pública, não só no trabalho. Especificamente, 0 autor analisa as formas como a religião civil, o estabelecimento cultural do cristianismo, a espiritualidade em amplo sentido e o secularismo continuam a competir em várias esferas da sociedade. Ademais, a obra não apresenta diferenciação entre aspectos de crenças ou práticas religiosas daqueles que são espirituais, na medida em que não é possível derivar conclusões das possíveis diferenças entre o comportamento de empregados no ambiente de trabalho e seu envolvimento regular com instituições fora do trabalho.

Outro ponto importante a ser considerado é a cautela na diferenciação entre assuntos de nível individual e institucional nas análises de quaisquer aspectos da cultura e dos valores. A linguagem utilizada pelos teóricos que estudam a questão de liderança e religião costuma ser bastante inapropriada. Como conseqüência desse uso impróprio, os líderes organizacionais acabam encobrindo as diferenças religiosas, espirituais e morais entre os funcionários, exigindo, ao mesmo tempo, que seus empregados tenham atitudes conflitantes com suas convicções pessoais.

A abordagem do autor enfatiza ainda os potenciais conflitos entre os comprometimentos religiosos, espirituais e morais de um lado, e as responsabilidades do empregador de outro. Para al guns empregadores, trata-se de uma competição de lealdades entre duas instituições: a empresa e os valores. É válido que os pesquisadores e as pessoas que lidam com o fenômeno na prática reflitam sobre a forma como os membros de comunidades religiosas em particular podem e devem "levar sua fé ao trabalho". Deve-se também atentar para a forma como os conflitos internos são negociados quando surgem pressões competitivas. 0 enfoque do autor nos conflitos engloba não só as tensões que surgem entre membros de uma força de trabalho diversificada, mas também a questão da competição entre as leal dades dos indivíduos que buscam integrar suas várias esferas de vida.

Assim, Religion and the Workplace é uma obra de significativa importância para o campo de conhecimento da administração. Ademais, sendo o Brasil um país que apresenta marcante sincretismo religioso, 0 livro pode auxiliar no entendimento dessa peculiar presença no cotidiano organizacional local. Desse modo, e como conclusão, cabe aos pesquisadores brasileiros adaptar as considerações a seu próprio contexto e buscar construções teóricas adequadas à nossa realidade. 